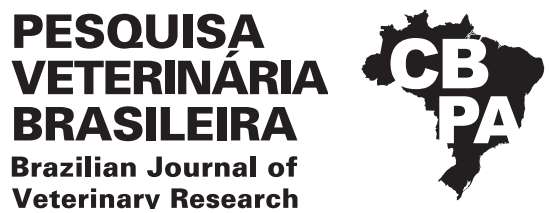

Pesq. Vet. Bras. 41:e06654, 2021

DOI: 10.1590/1678-5150-PVB-6654

Original Article

Small Animal Diseases

ISSN 0100-736X (Print)

ISSN 1678-5150 (Online)

\title{
Erythrocyte phenotyping for feline $A B$ system in domestic cats from the Ilhéus-Itabuna microregion, Bahia, Brazil ${ }^{1}$
}

\author{
Jamille B. Carvalho ${ }^{2}$, Camilla F. Oliveira², Paula Elisa B. Guedes ${ }^{2}$, \\ Katharine C. Santos ${ }^{2}$, Alexandre D. Munhoz ${ }^{3}$, Luciana A. Lacerda ${ }^{4}$ \\ and Renata S.A. Carlos ${ }^{3 *}$ (D)
}

\begin{abstract}
Carvalho J.B., Oliveira C.F., Guedes P.E.B., Santos K.C., Munhoz A.D., Lacerda L.A. \& Carlos R.S.A. 2021. Erythrocyte phenotyping for the feline AB system in domestic cats from the Ilhéus-Itabuna microregion, Bahia, Brazil. Pesquisa Veterinária Brasileira 41:e06654, 2021. Graduate Program in Animal Science, Departamento de Ciências Agrárias e Ambientais, Universidade Estadual de Santa Cruz, Campus Soane Nazaré de Andrade, Rodovia Jorge Amado Km 16, Bairro Salobrinho, Ilhéus, BA 45662-900, Brazil. E-mail: rsacarlos@uesc.br

This study aimed to determine the erythrocyte phenotypes of the feline $\mathrm{AB}$ system and to check the presence of antigens other than those present in the feline $A B$ system in domestic cats from Ilhéus-Itabuna microregion, Bahia, Brazil. Three-hundred feline blood samples were collected at the Veterinary Hospital of the "Universidade Estadual de Santa Cruz" (UESC) and in home visits to perform blood phenotyping using the tube-method testing. The reverse phenotyping was made between cats that tested phenotype B with blood samples of cats that tested phenotype A to confirm the blood phenotype B. The cross-tested among cats with phenotype $A$ was made in order to verify the presence of different antigens of $A B$ system in this blood phenotype. The results underwent macroscopic and microscopic analyses. Among the 300 animals tested, regarding breed, 290 were mixed-breed cats and among the remaining ten, five were Persians, four Siamese, and one Angora. 297 (99\%) presented with phenotype A (including all the breeding cats) and three (1\%) with phenotype B, and all this cats were mixed-breed cats. None $(0 \%)$ of the cats showed the phenotype AB. All phenotype B bloods reacted to reverse phenotyping with phenotype $A$, confirming the phenotype $B$ of these cats. All phenotype A bloods were compatible among each other, so no further erythrocyte antigens were detected through this test. The mother of one of the phenotype $\mathrm{B}$ cats was identified and had phenotype A, demonstrating phenotype A parents with phenotype B offspring. This finding indicates heterozygosis in the studied population. This data enable to conclude that the studied population presented different erythrocyte phenotypes, subsequently highlighting the importance of conducting phenotype analyses in these animals before performing blood transfusion to avoid serious hemolytic complications associated with incompatibility.
\end{abstract}

INDEX TERMS: Erythrocyte phenotyping, feline, AB system, domestic cats, Brazil, alloantibodies, blood cells, blood type, blood transfusion, cats.

\footnotetext{
${ }^{1}$ Received on July 28,2020 .

Accepted for publication on August 14, 2020.

${ }^{2}$ Graduate Program in Animal Science (PPGCA), Departamento de Ciências Agrárias e Ambientais (DCAA), Universidade Estadual de Santa Cruz (UESC), Campus Soane de Nazaré de Andrade, Rodovia Jorge Amado Km 16, Salobrinho, Ilhéus, BA 45662-900, Brazil. E-mails: camillafreitasvet@hotmail.com, paulaebg@gmail.com, mille.carvalho@hotmail.com.br, munhoz@uesc.br; *Corresponding author: rsacarlos@uesc.br

${ }^{3}$ Curso de Medicina Veterinária, Departamento de Ciências Agrárias e Ambientais (DCAA), Universidade Estadual de Santa Cruz (UESC), Campus Soane de Nazaré de Andrade, Rodovia Jorge Amado Km 16, Salobrinho, Ilhéus, BA 45662-900, Brazil. E-mail: kathycosta95@gmail.com

${ }^{4}$ Blut's Centro de Diagnósticos Veterinários, Rua Dr. Florêncio Ygartua 429, Porto Alegre, RS 90430-010, Brazil. E-mail: lulacerda20@hotmail.com
}

RESUMO.- [Fenotipagem eritrocitária para sistema AB felino em gatos domésticos da microrregão Ilhéus-Itabuna, Bahia, Brasil.] O objetivo deste estudo foi determinar a frequência dos fenótipos eritrocitários do sistema $A B$ felino e verificar a presença de outros antígenos, não pertencentes ao sistema $\mathrm{AB}$ felino, em gatos domésticos das cidades de Ilhéus e Itabuna, Bahia, Brasil. Amostras de sangue de 300 gatos foram coletadas no Hospital Veterinário da Universidade Estadual de Santa Cruz (UESC) e em visitas domiciliares para realizar a fenotipagem sanguínea usando o método de tubo. A fenotipagem reversa foi realizada em 
gatos que testaram o fenótipo $\mathrm{B}$ com amostras que testaram o fenótipo $\mathrm{A}$, para confirmação do fenótipo sanguíneo. $\mathrm{O}$ teste cruzado foi realizado entre gatos do fenótipo A, para pesquisar a presença de diferentes antígenos do sistema $\mathrm{AB}$ dentro desse fenótipo sanguíneo. Os resultados foram submetidos a análises macroscópicas e microscópicas. Dos 300 animais testados, 110 eram machos e 190 fêmeas, e suas idades variaram de cinco meses à 15 anos. Sobre as raças, 290 eram gatos sem raça definida e dos 10 restantes, cinco eram Persas, quatro eram Siameses e um Angorá. 297 (99\%) apresentaram fenótipo A (incluindo todos os gatos de raça) e três (1\%) tiveram fenótipo B, sendo todos esses gatos sem raça definida. Nenhum (0\%) dos gatos apresentou fenótipo $A B$. Todos os sangues com fenótipo $B$ reagiram na fenotipagem reversa com o fenótipo $\mathrm{A}$, confirmando o fenótipo $\mathrm{B}$ desses gatos. Todos os sangues com fenótipo A foram compatíveis entre si, portanto nenhum antígeno eritrocitário adicional foi detectado através deste teste. A genitora de um dos gatos com fenótipo $\mathrm{B}$, foi encontrada e a mesma possuía fenótipo A, demonstrando pais com fenótipo A e cria com fenótipo B. Esse achado indica heterozigose na população estudada. Esses dados levam à conclusão de que diferentes fenótipos eritrocitários estão presentes na população estudada e destacam a importância da realização de testes fenotípicos nesses animais antes dos procedimentos de transfusão, a fim de evitar complicações hemolíticas graves decorrentes do envolvimento de animais incompatíveis.

TERMOS DE INDEXAÇÃO: Fenotipagem eritrocitária, sistema AB, felinos, gatos domésticos, Brasil, aloanticorpos, células sanguíneas, tipo sanguíneo, transfusão sanguínea, gatos.

\section{INTRODUCTION}

Essentially, a feline blood type is composed of antigen complexes, present in the erythrocyte membrane, that can be determined by identifying at least two alleles in the same gene locus (Kehl et al. 2018). The feline AB system currently has three blood types; $\mathrm{A}$ is considered the most common, $\mathrm{B}$ is relatively rarer, and $\mathrm{AB}$ is the rarest of the three (Gurkan et al. 2005, Lacerda et al. 2008, Medeiros et al. 2008, Seth et al. 2011, Mendes et al. 2013, Teixeira-Pinto et al. 2016). Weinstein et al. (2007) reported the presence of a different erythrocyte antigen in the feline AB system, which was named "Mik."

Felines have preexisting antibodies against different erythrocyte antigens. Type-B animals have anti-A antibodies, which triggers severe hemolytic reactions when in contact with type-A blood (Bucheler \& Giger 1993). Type-A animals have anti-B antibodies that are incompatible with type-B blood and may produce mild to moderate reactions, considering the presence of weakly binding hemagglutinins and immunoglobulins. $\mathrm{AB}$ animals have neither anti-A nor anti-B alloantibodies (Bucheler \& Giger 1993). Cats with this blood phenotype can only receive type A or AB blood, since the type-B blood is rich in anti-A antibodies (Zheng et al. 2011, Kehl et al. 2018). Therefore, there is no blood group that can be considered as a universal donor in cats (Zheng et al. 2011, Kehl et al. 2018). The knowledge of compatibility in cats is important because each case of transfusion procedure in this specie is unique, and in hemotherapy, hemolytic severe reactions in receptors can lead them to death (McClosky et al. 2018).
Blood phenotyping and genotyping for allele determination in cats (whether heterozygous or homozygous) are critical to ensure blood compatibility (Casal et al. 1996, Zheng et al. 2011, Tasker et al. 2014, Karadjole et al. 2016). Several techniques are used to reveal the blood phenotyping in felines, like the tube test, the gel-columm method and the card method can be used (Seth et al. 2011).

The tube test is historically considered to be an excellent method and several studies in Brazil and worldwide have used this method for blood typing. Some of these studies include those from Mendes et al. (2013), Teixeira-Pinto et al. (2016), and Sorgatto et al. (2017) in Brazil; Arikan et al. (2006) in Turkey and Fosset \& Blais (2014) in Canada.

The prevalence varied in Brazil from 94.6\% (Guerra et al. 2007) to $98.5 \%$ (Sorgatto et al. 2017) for phenotype A; $0 \%$ (Sorgatto et al. 2017) to $4.73 \%$ (Guerra et al. 2007) for phenotype B; and 0\% (Teixeira-Pinto et al. 2016) to $1.5 \%$ (Sorgatto et al. 2017) for phenotype AB. In Turkey the authors found $73.1 \%$ for phenotype A, $24.6 \%$ for $B$ and $2.3 \%$ for $A B$ phenotype (Arikan et al. 2006) and in Canada it was found $94.4 \%$ for phenotype A, 5\% for B and $0 \%$ for AB (Fosset \& Blais 2014). Is important to notice that in all the studies cited, the majority of the population studied came from non pedigree cats.

Since this type of study is not typically performed in the northeast region of Brazil, we aimed to determine the prevalence of feline blood phenotypes and to identify the antigens that do not belong to the feline $A B$ group in the Ilhéus-Itabuna microregion of the state of Bahia.

\section{MATERIALS AND METHODS}

This research was approved by the Ethics Committee for the Use of Animals (CEUA) of the "Universidade Estadual de Santa Cruz" (UESC) under number 017/2016. Blood samples were collected from 300 domestic cats from the Ilhéus-Itabuna microregion after obtaining their owners' permission, in the UESC Veterinary Hospital and through scheduled home-visits. This samples were collected by convenience, regardless age or gender. The sample calculation was obtained through the estimate of the "Instituto Brasileiro de Geografia e Estatística" (IBGE 2013), which determined the number of $23.6 \%$ of households with cats in Bahia State. Also according to the IBGE, there are an estimated three people per residence. Taking into account these data and the average population of the municipalities Ilhéus and Itabuna (184.236 and 204.667 people respectively), with approximately 64,817 households and an estimated 15,296 cats. Based on these data, for the calculation of sample size, there was considered the previous prevalence of $94 \%$ of phenotype A (Guerra et al. 2007). However, this value is regarding to the whole country, and due to that we considered $99 \%$ of confidence interval and error of $5 \%$. The sample size calculation was performed with the EpiInfo ${ }^{\circledR}$ (versão 5.4.10), and the sample size was 149. The animals were wrapped in towels to prevent sudden movements or in bags of synthetic material designed to immobilize cats, according to the methods reported by Souza (2003), respecting cat friendly practice. Subsequently, 3-5mL of blood was collected from either the jugular or cephalic veins and distributed in two tubes with the same volume, one with an anticoagulant (EDTA-K2) and one without. The samples were then refrigerated at $2-6^{\circ} \mathrm{C}$ for a maximum duration of 72 hours (Arikan et al. 2003). The tubes without EDTA, were centrifuged to obtain the serum before been refrigerated. 
Blood phenotyping was performed according to a modification of the methodologies reported by Knottenbelt et al. (1999) and Stieger et al. (2005). At the time of the test, the tubes with EDTA were removed from refrigeration and thawed at room temperature. Following which, the samples were centrifuged at $1050 \mathrm{~g}$ for 5 minutes to separate the blood plasma and erythrocytes.

To verify the phenotype of the blood samples, we removed the plasma and leukocyte cap from each sample with a Pasteur pipette and added $4 \mathrm{~mL}$ of $0.9 \% \mathrm{NaCl}$ solution. The contents were carefully homogenized and centrifuged at $1050 \mathrm{~g}$ for 3 minutes. This procedure was repeated twice to completely wash the erythrocytes. Subsequently, we prepared a $5 \%$ erythrocyte solution using $50 \mu \mathrm{L}$ of the erythrocyte concentrate and $950 \mu \mathrm{L}$ of $0.9 \% \mathrm{NaCl}$ and placed it in a test tube. Continuing the test, three test tubes were identified for each sample and were labelled as: control tube (C), anti-A $(\alpha A)$ tube to identify phenotype $A$ and anti-B $(\alpha B)$ tube to identify phenotype B. In the control tube, $50 \mu \mathrm{L}$ of $0.9 \% \mathrm{NaCl}$ was added, the anti-A tube received $50 \mu \mathrm{l}$ of anti-A reagent (serum from an already tested animal B), and the anti-B tube contained $50 \mu$ l of anti-B reagent (Triticum vulgaris lectin). We consequently added $25 \mu \mathrm{L}$ of the previously prepared erythrocyte solution and gently homogenized the mixture. The three tubes were incubated for 15 minutes at room temperature and then centrifuged for 20 seconds at $1050 \mathrm{~g}$ to read the macroagglutination. After it, all the tubes were incubated in a water bath at $37^{\circ} \mathrm{C}$ for 15 minutes and centrifuged for 20 seconds at $1000 \mathrm{~g}$. At the end of the incubation process, the samples were observed for macroagglutination persistence and placed on slides and examined with a 10X-magnification optical microscope for possible microagglutinations. When the tube with anti-A reagent agglutinated, the cat was phenotype A. If the agglutination was in tube with anti-B reagent, the cat was phenotype B. And if the agglutination occurred in both tubes the cat had phenotype AB.

To confirm the phenotype $B$, a cross-match was made. All the procedure was similar to that of blood typing, except for the fact that in the tube was placed $50 \mu \mathrm{l}$ of serum of the animal A previously phenotyped and added $25 \mu$ l of the erythrocyte concentrate of the phenotype B animal to be confirmed. In other tube, $50 \mu \mathrm{l}$ of serum of the animal B was placed and added $25 \mu \mathrm{l}$ of the erythrocyte concentrate of the phenotype A animal. Both tubes had to have agglutination to confirm phenotype $\mathrm{B}$.

To check the presence of antigens other than those present in the feline $A B$ system, all samples with phenotype A collected on the same day underwent a major crossmatch in pairs, as a form of reverse typing. All the procedure was similar to that of blood typing, except for the fact that the anti-A or anti-B reagents were replaced by $50 \mu \mathrm{L}$ of animal serum. An aliquot of the sera from one day was also used in the crossmatch conducted on the animals the following day. Therefore, an additional $25 \mu \mathrm{l}$ of the previously prepared erythrocyte solution was added to the tube containing $50 \mu$ l of the sample serum. If any kind of agglutination was seen, indicated that a different $A B$ system antigen was found.

\section{RESULTS AND DISCUSSION}

Among the 300 feline samples, 110 were males and 190 females, and their ages ranged from five months to 15 years. Regarding breed, 290 were mixed-breed cats and among the remaining ten, five were Persians, four Siamese, and one Angora.

To perform phenotyping, the tube test, the gel-columm method and the card method can be used. The tube test was chosen to use in this study, because it is effective and economic (Stieger et al. 2005, Seth et al. 2011). Although the gel-column method is a standard for laboratories and has a high degree of specificity and sensitivity, it cannot be routinely used since it is particularly expensive and requires specific equipment. Other studies have used the card method, including those by Malik et al. (2005) and Vieira et al. (2017), but it also significantly more expensive than the tube test. Although the results of the tube method are dependent of the ability the observer to recognize the agglutination, this reaction is very easily recognizable and this method in previously studies had shown $91 \%$ and $99 \%$ of agreement with card and gel-columm methods respectively (Seth et al. 2011).

This is one of the largest population of subjects to be included for a national study in Brazil with this purpose (Mendes et al. 2013, Silva et al. 2016). Among the 300 animals tested, 297 (99\%) had blood phenotype A, three (1\%) had blood phenotype $\mathrm{B}$, and no animal presented with the blood phenotype $A B$. Most of the cats included in this study were mixed-breed class with the phenotype A. This corroborated with the outcomes of the studies conducted in in Brazil (Lacerda et al. 2008, Medeiros et al. 2008) as well as studies conducted in The United States, France, Croatia, and the Iberian Peninsula (Giger et al. 1989, Karadjole et al. 2016, Barrot et al. 2017, Vieira et al. 2017), which demonstrated that the majority of the feline population has phenotype A.

The present results differs from certain international studies (Arikan et al. 2003, Kehl et al. 2018) due to the population of cats used. These studies included populations of purebred breed cats, thereby highlighting the numerous phenotypic particularities in certain breeds, mainly with regard to blood phenotype B. It is imperative to note that the purebred cats used in the present study were of phenotype $A$, and that the phenotype B was found only in mixed-breed cats. The mother of one of the phenotype B cat was identified and was found to have phenotype A; therefore, demonstrating phenotype A parents with phenotype B offspring. This consequently indicated heterozygosis in the studied population, whereas two animals that have $\mathrm{Ab}$ alleles in their genotype are capable of generating offspring of genotype bb, and phenotype type B (Griot-Wenk et al. 1996).

Animals with the AB blood phenotype can be produced by crossing two animals with codominant alleles to express the two erythrocyte antigens, and not by crossing between cats with phenotypes A and B (Giger et al. 1991, Arikan et al. 2003). Therefore, animals of this blood phenotype are extremely rare. There were no AB animals in this study, which corroborated with other studies on mixed-breed cats in the United States, Turkey, and the Iberian Peninsula (Giger et al. 1989, Arikan et al. 2003, Vieira et al. 2017). Although the study by Arikan et al. (2003) primarily included purebred animals, it did not identify any specimens with this blood type, highlighting the importance of alleles in the expression of erythrocyte phenotypes. Contrary to our study outcomes, Silva et al. (2016) in Pará State, Brazil reported a higher prevalence of AB animals (1.28\%) over B animals ( $0.42 \%)$, possibly linked to the fact that there were more animals with codominant heterozygous alleles in the study region.

All RBCs samples from phenotype A animals agglutinated in contact with plasma from animals B, while those of phenotype A animals crossed with the plasma of animals of the same blood type did not, thus excluding the presence of incompatibility because of some non-AB system erythrocyte 
antigen, as described by Weinstein et al. (2007) and McClosky et al. (2018).

It is important to mention that although the percentage of phenotype B animals in this study was small, the animals had an important emotional significance for their owners. The need for a specific blood phenotype in the case of transfusion and the correspondingly low chance of finding a matching donor becomes a real and hard problem to resolve. Such a rarity makes it necessary to raise awareness among professionals in the area and to perform phenotyping analysis for the animals in the same region to broadly disseminate the results. Furthermore, it is also worth maintaining contact between the owners of cats with unusual phenotypes, to address the need for a possible transfusion in the future. One of the B animals was hit by a car and died during the study period. We informed the owners of the other two cats about the blood phenotype of their animals and established a mutual contact. All the owners were informed about the phenotype of their cats'.

\section{CONCLUSIONS}

Our study results indicated, in the Ilhéus-Itabuna microregion of the state of Bahia, high prevalence of blood phenotype A and slight presence of phenotypes $B$.

The result of cross-testing between animals of the same blood phenotype $(A)$ revealed no antigen other than the blood AB system. Our study also showed heterozygosis in the study population.

Acknowledgements.- To Dr. Luciana de Almeida Lacerda for the generously supplied reagents. We would like to thank the "Universidade Estadual de Santa Cruz" (UESC) for offering development conditions for this research, such as availability of laboratories and equipment.

Funding.- The authors would like to thank the "Fundação de Amparo à Pesquisa do Estado da Bahia" (FAPESB) for providing graduation scholarships. This study was financed in part by the "Coordenação de Aperfeiçoamento de Pessoal de Nível Superior” (CAPES), Brazil - Finance Code 001, for schoolarships.

Conflict of interest statement.- The authors report no conflicts of interest. The authors alone are responsible for the content and writing of the paper.

\section{REFERENCES}

Arikan S., Duru S.Y., Gurkan M., Agaoglu Z.T. \& Giger U. 2003. Blood type A and B frequencies in Turkish Van and Angora cats in Turkey. J. Vet. Med. 50(6):303-306. <https://dx.doi.org/10.1046/j.1439-0442.2003.00536.x> $<$ PMid:12887623>

Arikan S., Gurkan M., Ozaytekin E., Dodurka T. \& Giger U. 2006. Frequencies of blood type A, B and AB in non-pedigree domestic cats in Turkey. J. Small Anim. Pract. 47(1):10-13.<https://dx.doi.org/10.1111/j.1748-5827.2006.00005.x> $<$ PMid:16417604>

Barrot A.C., Buttin R., Linsart A., Bachy V., Guidetti M. \& Blais M.C. 2017. Frequency of feline blood types in non pedigree cats in France. Rev. Med. Vet., France, 168(10/12):235-240.

Bucheler J. \& Giger U. 1993. Alloantibodies against A and B blood types in cats. Vet. Immunol. Immunopathol. 38(3/4):283-295. <https://dx.doi. org/10.1016/0165-2427(93)90088-L ><PMid:8291206>

Casal M.L., Jezyk P.E. \& Giger U. 1996. Transfer of colostral antibodies from queens to their kittens. Am J. Vet. Res. 57(11):1653-1658. <PMid:8915447>

Fosset F.T.J. \& Blais M.C. 2014. Prevalence of feline blood groups in Montreal area of Quebec, Canada. Can. Vet. J. 55(2):1125-1128. <PMid:24381340>
Giger U., Bücheler J. \& Patterson D.F. 1991. Frequency and inheritance of A and B blood types in feline breeds of the United States. J. Hered. 82(1):1520. <https://dx.doi.org/10.1093/jhered/82.1.15><PMid:1997588>

Giger U., Kilrain C.G., Filippich L.J. \& Bell K. 1989. Frequencies of feline blood groups in the United States. J. Am. Vet. Med. Assoc. 195(9):1230-1232. <PMid:2584120>

Griot-Wenk M.E., Casal M.L., Chrisholm-Chait A., Spitalnik S.L., Patterson D.L. \& Giger U. 1996. Blood type AB in the feline AB group system. Am. J. Vet. Res. 57(10):1438-1442.<PMid:8896680>

Guerra T.A., Lacerda L.A., Oliveira S.T., Esteves V.S. \& González F.H.D. 2007. Tipagem sanguínea em felinos: 148 gatos domésticos na rotina laboratorial do Lacvet - UFRGS. Acta Sci. Vet. 35(Supl.2):s573-s574.

Gurkan M., Arikan S., Ozaytekin E. \& Dodurka T. 2005. Titres of alloantibodies against A and B blood types in non-pedigree domestic cats in Turkey: assessing the transfusion reaction risk. J. Feline Med. Surg. 7(5):301-305. <https://dx.doi.org/10.1016/j.jfms.2005.03.003> <PMid:15914059>

IBGE 2013. População de animais de estimação no Brasil. Instituto Brasileiro de Geografia e Estatística, Rio de Janeiro. Available at <http://www. agricultura.gov.br/assuntos/camaras-setoriais tematicas/documentos/ camaras-tematicas/insumos-agropecuarios/anos-anteriores/ibgepopulacao-de-animais-de-estimacao-no-brasil-2013-abinpet-79.pdf> Accessed on Dec. 28, 2018.

Karadjole T., Kovačević I., Samardžija M., Babić T., Kreszinger M., Radišić B., Harapin I. \& Bedrica L. 2016. Blood goups in cats in the city of Zagreb. Vet. Arhiv. 86(2):209-216.

Kehl A., Heimberger K., Langbein-Detsch I., Boehmer S., Raj K., Mueller E. \& Giger U. 2018. Molecular characterization of blood type A, B and C (AB) in domestic cats and a CMAH genotyping scheme. Plos One 13(9):e0204287. <https://dx.doi.org/10.1371/journal.pone.0204287><PMid:30235335>

Knottenbelt C.M., Addie D.D., Day M.J. \& Mackin A.J. 1999. Determination of the prevalence of feline blood types in the UK. J. Small Anim. Pract. 40(3):115-118. <https://dx.doi.org/10.1111/j.1748-5827.1999.tb03051.x> <PMid:10200921>

Lacerda L.A., Oliveira S.T., Guerra T.A., Stein G.G. \& González F.H.D. 2008. Prevalence of blood types A, B and AB in mixed breed domestic cats of Porto Alegre, Rio Grande do Sul, Brazil. Braz. J. Vet. Res. Anim. Sci. 45(Supl.):4653. <https://dx.doi.org/10.11606/S1413-95962008000700006>

Malik R., Griffin D.L., White J.D., Rozmanec M., Tisdall P.L., Foster S.F., Bell K. \& Nicholas F.W. 2005. The prevalence of feline A/B blood types in the Sydney region. Aust. Vet. J. 83(1/2):38-44. <https://dx.doi. org/10.1111/j.1751-0813.2005.tb12190.x ><PMid:15971816>

McClosky M.E., Brown D.C., Weinstein N.M., Chappini N., Taney M.T., Marryot K. \& Callan M.B. 2018. Prevalence of naturally occurring non-AB blood type incompatibilities in cats and influence of crossmatch on transfusion outcomes. J.Vet. Intern. Med. 32(6):1934-1942.<https://dx.doi.org/10.1111/ jvim.15334><PMid:30307648>

Medeiros M.A.S., Soares A.M., Alviano D.S., Ejzemberg R., Silva M.H. \& Almosny N.R. 2008. Frequencies of feline blood types in the Rio de Janeiro area of Brazil. Vet. Clin. Pathol. 37(3):272-276.<https://dx.doi.org/10.1111/j.1939165X.2008.00051.X><PMid:18761518>

Mendes R.S., Gurjão T.A., Souza A.P., Lacerda L.A. \& Silva R.M.N. 2013. Frequência dos antígenos eritrocitários do sistema $\mathrm{AB}$ em felinos domésticos no estado da Paraíba. Pesq. Vet. Bras. 33(6):780-784. <https://dx.doi.org/10.1590/ S0100-736X2013000600015>

Seth M., Jackson V. \& Giger U. 2011. Comparison of five blood-typing methods for the feline AB blood group system. J. Vet. Res. 72(2):203-209. <https:// dx.doi.org/10.2460/ajvr.72.2.203><PMid:21281194>

Silva P.B., Monteiro M.V.B., Silva R.R., Albuquerque M.R., Pereira A.C.A., Carreira A.S. \& Monteiro F.O.B. 2016. Frequência dos tipos sanguíneos de gatos domésticos oriundos do estado do Pará, Brasil. Acta Vet. Bras. 10(4):378-382. 
Sorgatto S., Oliveira B.B., Godoy K.C.S., Antunes T.R., Lacerda L.A. \& Souza A.I. 2017. Frequência dos tipos sanguíneos de gatos domésticos mestiços no município de Campo Grande, Mato Grosso do Sul, Brasil. Med. Vet., UFRPE, 11(3):172-178. <https://dx.doi.org/10.26605/medvet-n3-1778>

Souza H.J.M. 2003. Coletâneas em Medicina e Cirurgia Felina. LF Livros, Rio de Janeiro. p.289-300.

Stieger K., Palos H. \& Giger U. 2005. Comparison of various blood-typing methods for the feline AB blood group system. Am. J. Vet. Res. 66(8):13931399. <https://dx.doi.org/10.2460/ajvr.2005.66.1393><PMid:16173483>

Tasker S., Barker E.N., Day M.J. \& Helps C.R. 2014. Feline Blood genotyping versus phenotyping, and detection of non- $\mathrm{AB}$ blood type imcompatibilities in UK cats. J. Small Anim. Pract. 55(4):185-189. <https://dx.doi.org/10.1111/ jsap.12180><PMid:24697343>

Teixeira-Pinto A.B., Medeiros M.A.S., Jardim M.P.B. \& Albernaz A.P. 2016. Frequency of blood groups and titers of alloantibodies in domestic cats.
Ciênc. Anim. Bras. 17(2):222-235. <https://dx.doi.org/10.1590/10896891v17i213453>

Vieira S.M., Ferreira R.R.F., Matos A.J.F., Cardoso I.M., Graça R.M.C., Soares A.R.P.B., Blaisi-Brugué C., Sánchez I.M. \& Gopegui R.R. 2017. Distribution of feline $A B$ blood types: a review of frequencies and its implications in the Iberian Peninsula. JFMS Open Rep. 3(2):1-4. <https://dx.doi. org/10.1177/2055116917727693><PMid:28975035>

Weinstein N.M., Blais M.C., Harris K., Oakley D.A., Aronson L.R. \& Giger U. 2007. A newly recognized blood group in domestic shorthair cats: the Mik red cell antigen. J. Vet. Intern. Med. 21(2):287-292. <https://dx.doi. org/10.1892/0891-6640(2007)21[287:anrbgi]2.0.co;2><PMid:17427390>

Zheng L., Zhong Y., Shi Z. \& Giger U. 2011. Frequencies of blood types A, $\mathrm{B}$, and $\mathrm{AB}$ in non-pedigree domestic cats in Beijing. Vet Clin Pathol. 40(4):513-517.<https://dx.doi.org/10.1111/j.1939-165X.2011.00371.x> $<$ PMid:22092346> 